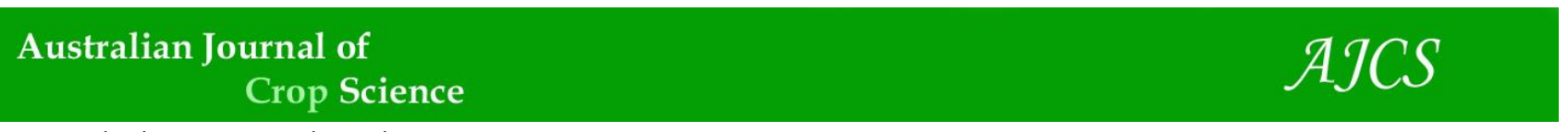

AJCS 14(11):1838-1843 (2020)

ISSN:1835-2707

doi: 10.21475/ajcs.20.14.11.p2891

\title{
Evaluation of nitrogen fertilization for planting corn in a yellow latosol under no- tillage system
}

\author{
Luana Paula Freire Souza ${ }^{1}$, Manoel Tavares Paula ${ }^{1^{*}}$, Carlos Alberto Costa Veloso ${ }^{2}$, Eduardo Jorge Maklouf \\ Carvalho ${ }^{2}$, Arystides Resende Silva ${ }^{2}$, Altem Nascimento Pontes ${ }^{1}$, Marcelo José Raiol Souza ${ }^{1}$, Claudia Viana \\ Urbinati ${ }^{1}$, Henriqueta da Conceição Brito Nunes ${ }^{1}$, Pedro Henrique Oliveira Simões ${ }^{3}$
}

${ }^{1}$ Center for Natural Sciences and Technology, University of the State of Pará, Belém-Pará-Brazil

${ }^{2}$ Soil Analysis Laboratory, Embrapa Eastern Amazon, Belém-PA-Brazil

${ }^{3}$ Department of Forest Sciences, Federal Rural University of Amazon, Belém-Pará-Brazil

\section{*Corresponding author: dpaulamt@hotmail.com}

\section{Abstract}

The objective of this work was to evaluate the efficiency of nitrogen fertilization in relation to the population of corn plants in a yellow latosol under no-tillage system. The experimental design was a randomized block with three replications, in a $4 \times 4$ factorial scheme, corresponding to four levels of $\mathrm{N}\left(0,60, \mathrm{~kg} \mathrm{ha}^{-1} 120\right.$ and 180) and four planting densities $(45,000 ; 55,000 ; 65,000$ and 75,000 plants $\mathrm{ha}^{-1}$ ). 48 soil samples were collected to determine chemical soil attributes ( $\mathrm{pH}, \mathrm{OM}, \mathrm{K}, \mathrm{Ca}, \mathrm{Na}, \mathrm{Mg}$ and $\mathrm{Al}$ ) and 48 leaf samples to determine macronutrients in the leaf ( $\mathrm{N}, \mathrm{P}, \mathrm{K}, \mathrm{Na}, \mathrm{Ca}$ and $\mathrm{Mg}$ ). The data were submitted to comparison of means by the Scott-Knott test. The corn yield increased linearly up to the dose of $180 \mathrm{~kg} \mathrm{ha}^{-1} \mathrm{~N}$. Higher productivity was observed with the combination of 120 and $180 \mathrm{~N}\left(\mathrm{~kg} \mathrm{ha}^{-1}\right)$ with the density of 75,000 plants ha ${ }^{-1}$. There was an increase in the $\mathrm{N}$ content in the leaves with increasing doses of $\mathrm{N}$ in the soil.

Keywords: Amazon, Fertilizer, Oxisols, Zea mays.

Abbreviations: SOM_Soil Organic Matter; V\%_base saturation; NTS_no-till system; $\mathrm{kg} \mathrm{ha}^{-1}$ _ kilogram per hectare; $\mathrm{g} \mathrm{kg}^{1}$ _. gram per kilogram; plants ha ${ }^{-1}$ _plants per hectare; $\mathrm{R}^{2}$ _determination coefficient; $\mathrm{N}_{\text {nnitrogen; }}$ __phosphor; K_potassium; Ca_calcium; Mg_magnesium; $\mathrm{Na}$ _sodium.

\section{Introduction}

Maize constitutes as one of the main cereals in the world. Brazil, has achieved high productivity due to changes in managements and cultural practices, (Farinelli et al., 2012). In the season 2014/2015 the state of Pará accounted for 706,800 tons of domestic production of corn grain (Conab, 2016).

Large amounts of nutrients are applied through fertilizers in grain production in Pará. Nitrogen $(\mathrm{N})$ is the nutrient required in larger quantities and that most influences corn yield also is the main factor that burdens the cost of production of this crop (Melo, 2011). Despite its great importance, usually soils do not supply the demand for nutrient required by the crop, which is necessary to carry out fertilization.

Generally, nitrogen fertilization recommendations are based on crops grown under conventional systems with the intensive use of mechanization and pesticides, added to monocultures, contributing to soil degradation over the years of use, decreasing the edaphic quality for cultivation and allowing events like erosion (Olivera, et al., 2015). Thus, the scenario of expansion of grain production in Brazil requires the search for sustainable production alternatives, as the current agricultural model adopted in this process causes serious problems, especially for the environment (Souza, 2016).

According to Cassol et al. (2007), there is no-till system (NTS) which is an alternative to the conventional system commonly used for grain production. NTS is a conservation management system consisting of practices that necessarily involve crop rotation and soil mobilization exclusively in the sowing line and permanent soil cover. The no-till system is essential to increase corn productivity in the soils of tropical and subtropical regions. It reduces soil degradation and loss (Merten et al., 2015), reduces water stress, controls temperature and acidity, and increases the quality of the properties of the physical-chemical attributes and organic matter of the soil (Bolan et al., 2008; Valentinuzzi et al., 2015, Caires et al., 2015, Oliveira, et al., 2015 , Holland et al., 2018, Nogaroli and Fonseca (2020).

The $\mathrm{N}$ is one of the nutrients with greater interactions with the environment, with losses of $\mathrm{N}$ that generate economic and environmental damage, soil type dependent, climate, soil tillage and fertilizers (Cantarella et al., 2010), hence the importance to achieve maximum efficiency in the use of these inputs. 
The search for the best arrangement of plants is among the various factors that influence productivity. In maize, the best distribution of plants can be accomplished by changes in spacing and plant density (Sangoi, 2000).

Considering the local characteristics and the lack of information in the conditions of the western state of Pará, there is a need for further studies on the adequacy of doses and fertilizer management practices to increase the efficiency in the use of nitrogen fertilizers (Veloso, 2012), especially before expansion of agriculture grain cultivation in the state of Pará. Such studies will maximize the efficiency of fertilizer use, especially in the NTS, reducing costs for the producer and minimizing environmental impacts.

In this context, the objective of this work was to evaluate the efficiency of nitrogen fertilization in relation to the population of corn plants in a yellow latosol under no-tillage system. Our hypothesis was that (1) the different levels of nitrogen fertilization and planting density influence corn productivity and the content of leaf $\mathrm{N}$, and (2) the no-tillage system offers better sustainability for corn planting in tropical regions, as it improves chemical attributes of the soil.

\section{Results and Discussion}

\section{Maize productivity as a function of $\mathrm{N}$ doses}

Nitrogen application had a significant effect $(p<0.05)$ on corn grain yield. Yield was increased linearly (Fig 1) in relation to $\mathrm{N}$ doses, with increased productivity $(6795.3 \mathrm{~kg}$ $\left.\mathrm{ha}^{-1}\right)$, obtained with the highest $\mathrm{N}$ dose $\left(180 \mathrm{~kg} \mathrm{~h}^{-1}\right)$. Similar effects have also been observed in other studies with corn (Duete et al., 2008; Gomes et al., 2007; Kappes et al., 2014; Queiroz et al, 2011; Veloso et al., 2012). It is worth mentioning that the highest dose of study $\mathrm{N}$ evaluated in the study is higher than the maximum dose of $\mathrm{N}\left(100 \mathrm{~kg} \mathrm{ha}^{-1}\right)$ recommended for the cultivation of corn in the state of Pará, as described by Cravo et al. (2007). This indicates that, possibly due to differences in climatic conditions and soil type, the dose that provides the best performance of the corn may vary.

The increase in productivity in a linear fashion, increasing with the increase in nitrogen doses, demonstrates that this hybrid can respond to higher doses than those used in this study. The increase in grain yield with increased doses may be related to the release of nitrogen in the soil or the application of the nutrient, according to Queiroz et al. (2011). The use of high doses of $P$ and $K$ applied as basic fertilization, can provide a better use of $\mathrm{N}$ in the soil.

To study the effect of doses 0 to $150 \mathrm{~N} \mathrm{~kg} \mathrm{ha}^{-1}$ on the soil NTS in the state of Mato Grosso do Sul, Kappes et al. (2014) obtained $9846 \mathrm{~kg} \mathrm{ha}^{-1}$ of maximum productivity at a dose of $100 \mathrm{~kg} \mathrm{ha}^{-1}$. Gomes et al. (2007) also used doses from 0 to $150 \mathrm{~kg} \mathrm{ha}^{-1}$ in corn under the no-tillage system in the state of Goiás, and obtained a maximum yield of $7,012 \mathrm{~kg} \mathrm{ha}^{-1}$ of corn grains.

When assessing nitrogen levels from 0 to $120 \mathrm{~kg} \mathrm{ha}^{-1}$ in a dystrophic yellow latosol in the eastern Amazon, Veloso et al. (2012) observed that the yield was increased linearly in relation to the doses of $\mathrm{N}$ applied, with the maximum productivity obtained with the highest dose. Queiroz et al. (2011), applied doses of $0-160 \mathrm{~kg} \mathrm{ha}^{-1}$ in five years of cultivation, the last two with minimum planting and corn planting also had an increasing linear effect on grain yield.
However, different results were obtained by Ferreira et al. (2009), who studied corn grown in oat straw in the state of Paraná. They observed a decrease in corn productivity in doses above $165 \mathrm{~N} \mathrm{~kg} \mathrm{ha}^{-1}$. Silva et al. (2005), analyzed the levels of $N\left(0,60,120\right.$ and $\left.180 \mathrm{~kg} \mathrm{ha}^{-1}\right)$ applied at different times in no-tillage system in the state of Mato Grosso do Sul. They concluded that the dose of $166 \mathrm{~kg} \mathrm{ha}^{-1}$ provided maximum efficiency $\left(7,475 \mathrm{~kg} \mathrm{ha}^{-1}\right)$. Melo et al. (2011) used $\mathrm{N}$ doses from 0 to $200 \mathrm{~kg} \mathrm{ha}^{-1}$ in maize in six years under notillage system in the state of Maranhão and reached the maximum yield of corn grains at a dose of $120 \mathrm{~kg} \mathrm{ha}^{-1}$.

Farinelli and Lemos (2010) evaluated the productivity and agronomic efficiency of corn for nitrogen fertilization and soil management in São Paulo. They found that the maximum grain yield was obtained by application of $92 \mathrm{~kg}$ $\mathrm{ha}^{-1}$ of $\mathrm{N}$ under cover the greatest gains and the yield per $\mathrm{kg}$ of $\mathrm{N}$ applied in the SPD compared to the conventional system.

\section{Interaction between $\mathbf{N}$ fertilization and plant density}

According to Mendes et al. (2011), the interaction between nitrogen fertilization and planting density on the agronomic traits of corn are influenced by the choice of hybrid. The recommended population to maximize maize grain productivity ranges from 40,000 to 80,000 plants per hectare (Cruz et al., 2010).

Different responses in corn production were obtained between the relationship of $\mathrm{N}$ doses with planting densities (Table 1). Significant effect was observed $(p<0.05)$ in the interaction of $\mathrm{N}$ doses with planting densities of 45,000 , 55,000 and 65,000 plants ha $^{-1}$. However the combination of doses 120 and $180 \mathrm{~N}$ with density of 75,000 plants ha ${ }^{-1}$ showed higher values of productivity $(p<0.05)$ in relation to doses of 0,60 and $120 \mathrm{~N}$, which did not differ statistically from each other.

Table 1 considers the productivity within each planting density as a function of the doses. It is noted that the planting densities of 55,000, 65,000 and 75,000 plants ha ${ }^{-1}$ has higher productivity values at doses of 0,120 and $180 \mathrm{~N}$ in comparison with the dose of $60 \mathrm{~N}$. For the planting density of 45,000 plants $h^{-1}$, no significant difference ( $P$ > 0.005 ) was observed in corn productivity between the doses of $\mathrm{N}$.

With the minimum dose of nutrient used in this study $(60 \mathrm{~kg}$ $\mathrm{ha}^{-1}$ ), an average yield corn grains (5791.9 $\mathrm{kg} \mathrm{ha}^{-1}$ ) was obtained of (Table 1) that exceeds the average for the state of Pará of only $3,232 \mathrm{~kg} \mathrm{ha}^{-1}$ (Conab, 2016) and is higher than the national average of $5,396 \mathrm{~kg} \mathrm{ha}^{-1}$ (Conab, 2016).

Gross et al. (2006), cultivated corn under no-tillage system in the state of Minas Gerais. They indicated that the density of $55,000,70,000$ and 85,000 plants $\mathrm{ha}^{-1}$ does not have significant influence on the planting density as grain yield. However, Alvarez et al. (2006) mentioned that increasing the density from 55,000 to 75,000 plants ha $^{-1}$, causes increase in productivity regardless of the year of cultivation, spacing between rows and cultivar.

The increase in population density in the corn crop is one of the factors that can contribute to the correct exploitation of the environment and of the genotype and the environment. However, it can cause greater competition between plants for nutrients, light, water and $\mathrm{CO}_{2}$, being that the availability 
Table 1. Productivity of corn kernels per treatments, in an yellow latosol under no-tillage system.

\begin{tabular}{|c|c|c|c|c|c|c|c|c|}
\hline treatments & \multicolumn{8}{|c|}{ Planting density (plants ha ${ }^{-1}$ ) } \\
\hline Nitrogen doses $\left(\mathrm{Kg} \mathrm{ha}^{-1}\right)$ & 45.000 & & 55.000 & & 65.000 & & 75.000 & \\
\hline 0 & 5181.53 & $\mathrm{Aa}$ & 4046,17 & $\mathrm{Aa}$ & 4245.59 & $\mathrm{Aa}$ & 4624.97 & $\mathrm{Aa}$ \\
\hline 60 & 7480.55 & $\mathrm{Aa}$ & 5687,60 & $A b$ & 5341.29 & $A b$ & 4658.08 & $A b$ \\
\hline 120 & 5457.02 & $\mathrm{Aa}$ & 5487,75 & $\mathrm{Aa}$ & 5714.82 & $\mathrm{Aa}$ & 6151.27 & $\mathrm{Ba}$ \\
\hline 180 & 6591.29 & $\mathrm{Aa}$ & 7060,75 & $\mathrm{Aa}$ & 7039.22 & $\mathrm{Aa}$ & 6966.13 & $\mathrm{Ba}$ \\
\hline
\end{tabular}

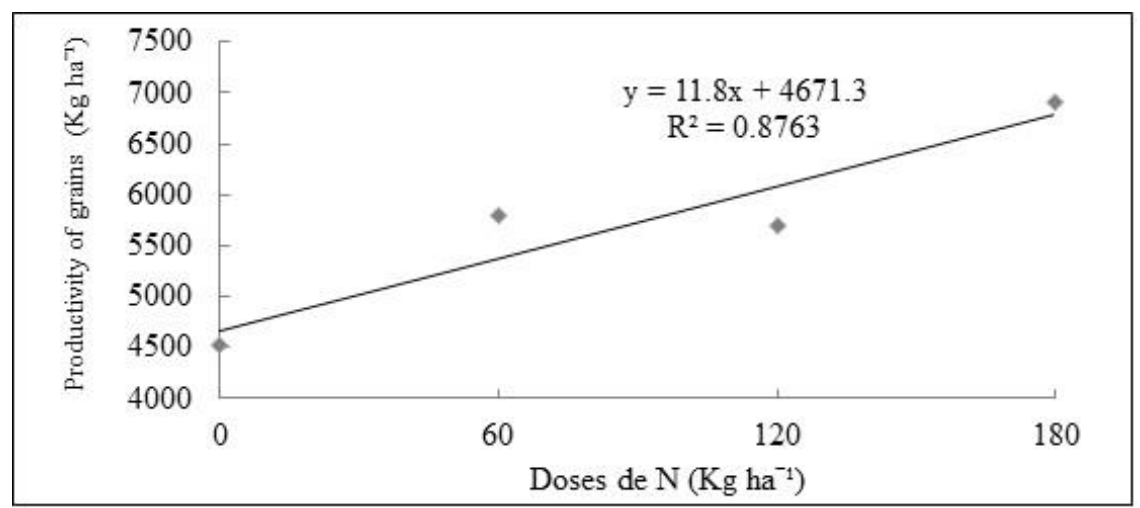

Fig 1. Productivity of grains in doses of nitrogen function, in an yellow latosol under no-tillage system.

Table 2. Levels of nutrients in the medium corn leaves at flowering in doses of nitrogen function, in an yellow latosol under notillage system.

\begin{tabular}{|c|c|c|c|c|c|c|c|c|c|c|c|c|}
\hline \multirow{2}{*}{$\begin{array}{l}\text { Nitrogen } \\
\mathrm{ha}^{-1} \text { ) }\end{array}$} & \multirow{2}{*}{ Dose } & \multirow{2}{*}{ (Kg } & \multicolumn{10}{|c|}{ Content foliar } \\
\hline & & & $\mathrm{N}$ & & $P$ & & K & & $\mathrm{Ca}$ & & $\mathrm{Mg}$ & \\
\hline 0 & & & 24.67 & $a$ & 1.62 & $a$ & 89.35 & $a$ & 6.17 & $a$ & 2.76 & A \\
\hline 60 & & & 25.03 & $a$ & 1.84 & $a$ & 113.28 & $a$ & 6.77 & $\mathrm{~b}$ & 2.68 & A \\
\hline 120 & & & 25.48 & a & 1.87 & a & 102.87 & a & 6.79 & $b$ & 2.78 & A \\
\hline 180 & & & 25.75 & a & 1.90 & a & 98.83 & $\mathrm{a}$ & 5.76 & $\mathrm{a}$ & 2.42 & A \\
\hline
\end{tabular}

Means followed by the same letter are not statistically different from each other by the Scott-Knott test at $5 \%$ probability.

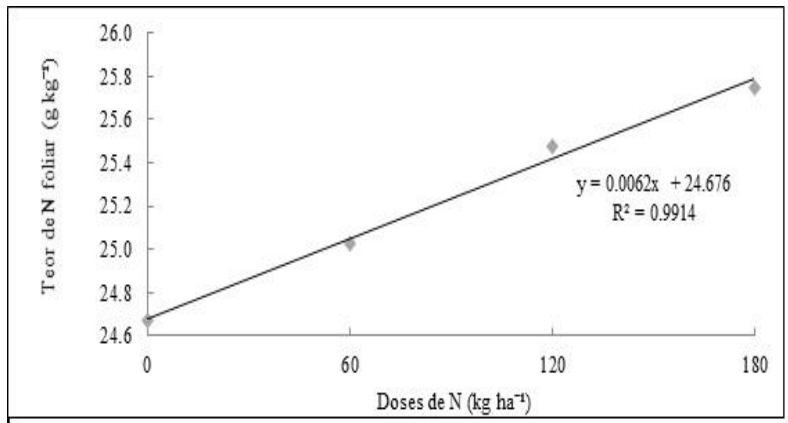

Fig 2. Total nitrogen content in maize leaves, depending of nitrogen, in an yellow latosol under no-tillage system.

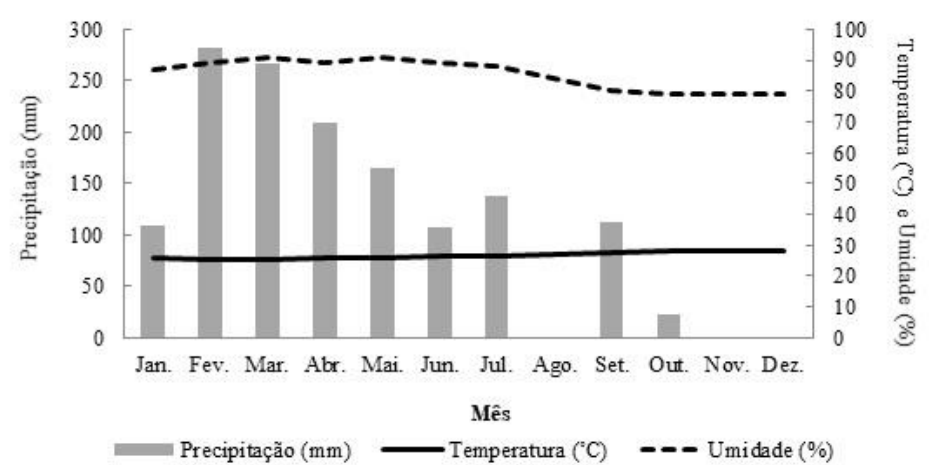

Fig 3. Monthly data of average temperatura, rainfall and reative humidity in the year 2015. Source: Inmet, 2015. 
of nutrients and water are the factors that offer the most limitations for planting large populations of plants (Von Pine et al., 2008), resulting in lower crop yields.

\section{Leaf $\mathrm{N}$ content as a function of planting doses}

According to Fig 2, there is a linear increase in the $\mathrm{N}$ content in the leaf tissue, as a function of the various doses of applied nutrients. The equation that best fitted presented an $\mathrm{R}^{2}$ determination coefficient of 0.99 , indicating that $99 \%$ of the variation in the $\mathrm{N}$ content in the leaf tissue is explained as a function of the $\mathrm{N}$ doses applied to the soil.

The increase in the $\mathrm{N}$ content in the leaf with the increase in the $\mathrm{N}$ doses (Fig 2) was also observed in other studies. Andrade et al. (2014) used nitrogen levels from 0 to $200 \mathrm{~kg}$ $\mathrm{ha}^{-1}$ and obtained the highest $\mathrm{N}$ accumulation in the leaves with the last dose. However, the highest yields were observed with the application of 130-145 kg N.

The concentrations of macronutrients $\mathrm{N}, \mathrm{P}, \mathrm{K}$ and $\mathrm{Mg}$ in the leaf tissue did not show significant differences $(P>0.05)$, depending on the nitrogen doses applied to the soil. However, the macronutrient $\mathrm{Ca}$ was significantly affected ( $\mathrm{P}$ $<0.05$ ) due to the different amounts of $\mathrm{N}$, and the highest $\mathrm{Ca}$ values were observed at doses of 60 and $120 \mathrm{~N}$, compared to doses from 0 to 180 doses, which did not differ from each other $(P>0.05)$. Possibly, the supply of nitrogen to plants by the reserve of organic matter in the soil caused a smaller discrepancy in the $\mathrm{N}$ levels between treatments (Kaneko et al., 2010).

The values for the $\mathrm{N}$ content in the leaves are below those considered suitable for the crop (27 to $35 \mathrm{~g} \mathrm{~N}$. $\mathrm{kg}^{1}$ of dry matter), according to the recommendations of Raij (2011), which allows to infer that if the content of $\mathrm{N}$ in the leaves were within the range considered adequate, it would be possible to obtain even greater productivity than those found in this study.

By evaluating doses of $\mathrm{N} 40-340 \mathrm{~kg} \mathrm{ha}^{-1}$ Santos et al. (2013) found that leaf $C$ ranged from 25.1 to $30.1 \mathrm{~g} \mathrm{~kg}^{1}$ and higher productivity of corn kernels was achieved with doses of 316 and $340 \mathrm{~kg} \mathrm{ha}^{-1}$, respectively, for direct and conventional tillage.

In the present study, a positive relationship was observed between the amount of $\mathrm{N}$ present in the leaves and grain yield, where there was a greater accumulation of nitrogen in the leaves, the highest yields occurred.

Considering the concentration of macronutrients in the leaves as a function of planting densities, we observed that the average levels of $\mathrm{N}, \mathrm{P}, \mathrm{Ca}$ and $\mathrm{Mg}$ in the leaf tissue did not show significant differences $(P>0.05)$ due to the different planting densities. However, the $K$ content was significantly affected $(P<0.05)$ due to the different planting densities, with the lowest $K$ value being observed at the density of 55,000 plants $\mathrm{ha}^{-1}$ compared to the densities of $45,000,65,000$ and 75,000 plants $h^{-1}$, which showed no differences in $\mathrm{K}$ leaf content $(P<0.05)$.

In the first five years under NTS, the need for nitrogen is high due to the immobilization of this nutrient in the straw of crops (Anghinoni, 2007). However, with the continuity of the system and its stabilization, the availability of nutrients for the plants increases. In addition, the quality of the soil and the advantages associated with it considerably reduce the need for nitrogen, and fertilization.

Kurihara et al. (1998) observed that after four years of applying NTS, accumulation of nutrients in the superficial layers of the soil will increase, mainly in the first five centimeters. As this research was the first of the year in which the no-till system was implemented, it is expected to obtain better results for crops in subsequent years.

Considering the equation obtained to estimate grain yield with a nitrogen dose of $250 \mathrm{~kg} \mathrm{ha}^{-1}$ it would be possible to obtain approximately $7621.3 \mathrm{~kg} \mathrm{ha}^{-1}$ of corn grains, with the same nutrient dose. Santos et al. (2013) obtained an average yield of $13,000 \mathrm{~kg} \mathrm{ha}^{-1}$ in a NTS in five years, which shows the potential of this type of long-term system.

Note that the variations in the results of nitrogen fertilization experiments on corn are due to the diversity of climatic and soil conditions prevailing in the country (biotic and abiotic factors) and the different conditions, under which each study is carried out (Okumura, 2011). Another important factor that would be affecting the efficiency of $\mathrm{N}$ fertilization in the tests would be the genetic differences of the materials (Okumura, 2011).

Despite the variations in the results of the work with nitrogen fertilization, it can be said that the western region of the State of Pará has great potential for the cultivation of grains under no-tillage system, mainly corn, the crop was used in this study. However, the values of productivity of corn grains are still low compared to the yields obtained in other regions of Brazil with the same type of system, such as the Midwest and the Southeast.

\section{Materials and methods}

\section{Site and soil description}

The experiment was conducted in the Experimental Field of Embrapa Amazônia Oriental, municipality of Belterra, microregion of Santarém, located $03^{\circ} 7^{\prime} 45.64$ "S and $55^{\circ} 3^{\prime} 0.88^{\prime \prime}$ W, Pará, Brazil, in a dystrophic yellow latosol, very clayey texture (Embrapa, 2013). The soil collection was carried out before planting for chemical and physical measurements, following the methodology described in Embrapa (1997), having the following chemical properties at a depth of $0-20$ $\mathrm{cm}: \mathrm{pH}\left(\mathrm{H}_{2} \mathrm{O}\right)=4.6 ; \mathrm{SOM}=35.0 \mathrm{~g} \cdot \mathrm{kg}^{-1} ; \mathrm{P}$ Mehlich $=3 \mathrm{mg} . \mathrm{dm}^{-}$ ${ }^{3} ; \mathrm{K}=0.13 \mathrm{cmol}_{\mathrm{c} \mathrm{dm}} \mathrm{dm}^{-3} \mathrm{Ca}=1.4 \mathrm{cmol}_{\mathrm{c}} \mathrm{dm}^{-3} ; \mathrm{Mg}=0.2 \mathrm{cmol}_{\mathrm{c}}$ $\mathrm{dm}^{-3} ; \mathrm{H}+\mathrm{Al}=5.7 \mathrm{cmol}_{\mathrm{c}} \mathrm{dm}^{-3}$ and $\mathrm{V}=23.06 \%$; sand $(20 \%)$; sludge (22\%) and clay (58\%).

The climate, according to Koppen's classification, is of the Am type (hot and humid), with an average precipitation of $1,900 \mathrm{~mm}$ and an altitude of $175 \mathrm{~m}$. The months with the highest rainfall in the experiment period were February to April (Fig 3), according to data obtained from a conventional meteorological station (Inmet, 2015).

\section{Experimenal design and conduction of study}

To correct the acidity of the soil, $1.5 \mathrm{t} \mathrm{ha}^{-1}$ of limestone (90\% PRNT) was applied throughout the area. The correction was applied to increase the base saturation (V\%) of the soil by $60 \%$, according to Raij et al. (1996). All plots received basic fertilization with application of $90 \mathrm{~kg} \mathrm{~kg} \mathrm{ha}^{-1}$ of $\mathrm{P}_{2} \mathrm{O}_{5}$ and 90 $\mathrm{kg} \mathrm{ha}^{-1}$ of $\mathrm{K}_{2} \mathrm{O}$. The forms of superphosphate $(\mathrm{P})$ and potassium chloride $(\mathrm{K})$ were applied in the furrow close to the culture lines. The application of potassium (K) was divided in two, with $1 / 3$ at the time of planting and the remaining $2 / 3$ in coverage between the lines, together with the second application of $\mathrm{N}$. Nitrogen was applied in coverage in the form of urea, $25 \%$ at planting and $75 \%$ after 25 days. Shortly after corn planting, Brachiaria grass (Brachiaria ruziziensis) was planted, considering that corn 
was the first crop in the system and that the principles of notillage systems are permanent soil cover.

The experimental design was a randomized block design with three replications in a factorial $4 \times 4$ corresponding to four $\mathrm{N}$ levels $\left(0,60,120\right.$ and $\left.180 \mathrm{~kg} \mathrm{ha}^{-1}\right)$ in the form of urea $(45 \% \mathrm{~N})$ and four densities planting: 45,000; 55,000; 65,000 and 75,000 plantas ha ${ }^{-1} .48$ experimental plots were used, distributed in three blocks. The total area of each block was $875 \mathrm{~m}^{2}(25 \times 35 \mathrm{~m})$ and each plot $40 \mathrm{~m}^{2}(5 \times 8 \mathrm{~m})$, with spacing of $0.7 \mathrm{~m}$ between planting rows of $8 \mathrm{~m}$. We collected 48 soil samples in the depth $0-20 \mathrm{~cm}$ for determining soil chemical properties: $\mathrm{pH}\left(\mathrm{H}_{2} \mathrm{O}\right), \mathrm{SOM}, \mathrm{P}, \mathrm{K}, \mathrm{Ca}, \mathrm{Na}, \mathrm{Mg}$ and $\mathrm{Al}$ and 48 leaf samples for determination of macronutrients $\mathrm{N}$, $\mathrm{P}, \mathrm{K}, \mathrm{Na}, \mathrm{Ca}$ and $\mathrm{Mg}$.

The simple hybrid AG 7088 NEXT was used for sowing, which has characteristics of semi-early cycle, high productivity and production stability. Flowering started on March 30, 2015 and, at the time of complete flowering, 30 leaves were collected below the ear of corn, per treatment. Two central rows of each experimental plot were considered. The harvest was carried out manually on $06 / 10 / 2015$ to obtain grain yield. The yield was obtained by weighing the ears of grains harvested in the useful area of the plots, extrapolating the production of the useful area of the portion $\left(22.4 \mathrm{~m}^{2}\right)$ to one hectare and the weight of the grains was corrected by $13 \%$ moisture. All analyzes of soil and plant tissues (Carmo et al., 2000) were carried out at the Soil Analysis Laboratory of Embrapa Amazônia Oriental (Embrapa, 1997).

\section{Statistical analysis}

The data were submitted to analysis of variance (ANOVA) by the $\mathrm{F}$ test and the means were compared by the Scott-Knott test at $5 \%$ probability, using the statistical program Sisvar 5.6 (Ferreira, 2011). Regression equations were also performed for the studied variables, depending on nitrogen levels.

\section{Conclusions}

$\mathrm{N}$ doses had a significant effect on grain yield, which increased linearly as a function of doses, with the maximum yield corresponding to a dose of $180 \mathrm{~kg} \mathrm{ha}^{-1}$. Higher corn yield values were observed with the combination of 120 and $180 \mathrm{~N}$ doses with 75,000 density plants ha ${ }^{-1}$. There was an increase in the $\mathrm{N}$ content in the leaf with increasing doses of $\mathrm{N}$. The macronutrient $\mathrm{Ca}$ in the leaf tissue was affected due to the different doses of nitrogen in the soil, with higher values in the doses of 60 and $120 \mathrm{~N}$, the other macronutrients $\mathrm{N}, \mathrm{P}, \mathrm{K}$ and $\mathrm{Mg}$ were not affected due to different doses of $\mathrm{N}$.

\section{Acknowledgements}

The authors are grateful to the Embrapa Amazônia Oriental Soil Laboratory for their contribution to the development of this research and to the Coordination of Improvement of Higher Education Personnel (Capes), which, through the Amazon Foundation for Research and Research (Fapespa), financed the scholarship for research.

\section{References}

Andrade FR, Petter FA, Nobrega JCA, Zuffo AM (2014) Performance agronomic corn to nitrogen doses and application times in Piauí Cerrado. ASJ. 57: 358-66.
Anghinoni, I (2007) Soil fertility and its management in no-till system. In: Novais RF, Alvarez VH, Barros NF, Sources RLF, Cantarutti RB, Neves JCL Soil fertility. Viçosa: Brazilian Society of Soil Science. 1: 873-928.

Bolan NS, Rowarth J, de la Luz Mora M, Adriano D, Curtin D (2008) Biological transformation and bioavailability of nutrient elements in acid soils as affected by liming. In Naidu, R. (ed.), Chemical Bioavailability in Terrestrial Environments. Elsevier B.V.

Caires EF, Haliski A, Bini AR, Scharr DA (2015) Surface liming and nitrogen fertilization for crop grain production under no-till management in Brazil. Eur J Agron. 66:4153.Cantarella H, Montezano FZ (2010) Nitrogen and sulfur. In: Prochnow, L. I, Casarin, V., Stripp, SR Good practices for the efficient use of fertilizers. Piracicaba: IPNI. 2:1-46.

Carmo CAFS, Araujo WS, Bernardi ACC, Saldanha MFC (2000) Plant tissue analysis methods used in the Embrapa soils. Rio de Janeiro: Embrapa Solos. Technical Circular. 41:1-6.

Cassol EA, Denardin JE, Kochhann RA (2007) Tillage system: Development and implications on the conservation of soil and water. In: Ceretta, CA, Silva, LS, Reichert JM (ed.). Topics in soil science. Lush: Brazilian Society of Soil Science. 5: 333-370.

Conab (2016) Brazilian crop: grains, 10th survey. Brasilia: Conab. Available in: http://www.conab.gov.br/ conteúdos.php >. Access on: january. 10st, 2016.

Cravo MS, Silveira Filho A, Rodrigues JEL, Veloso CAC (2007) Corn. In: Carnation, MS, Viégas, IJM, Brazil, EC Recommendations fertilization and liming for the State of Belém do Pará: Embrapa Amazônia Oriental. 84:1-15.

Cruz JC, Filho IAP, Alvarenga RC, Neto MMG, Viana JHM, Oliveira MF, Mantragolo WJR, Filho, MRA (2010) Embrapa Maize and Sorghum. Production system. Electronic version. $6 . \quad$ ed. Available in: $<$ http://www.cnpms.embrapa.br/publicações. htm.>. access on: november. 15st, 2016.

Embrapa (1997) National Center for Soil Research (Rio de Janeiro, RJ). Manual of soil analysis methods. Rio de Janeiro. 2:1-212.

Embrapa (2013) National Center for Soil Research. Brazilian system of soil classification. 3. ed. Rio de Janeiro: Embrapa Solos. 3:1-353.

Duete RRC, Muraoka TM, Silva EC, Trivelin PCO, Ambrosano EJ (2008) Management of nitrogen fertilization and utilization of nitrogen (15N) by corn crop in Red Latosol. Journal of Soil Science. 32:161-171.

Farinelli R, Penariol FG, Fornasieri Filho D (2012) Agronomic characteristics and productivity of corn cultivars with different row spacings and densities. Science. 40: 21-27.

Farinelli R, Lemos LB (2010) Productivity and agronomic efficiency of corn to nitrogen fertilization and soil managements. Journal of Maize and Sorghum. 9:135-146.

Ferreira AO, Sa JCM, Briedis C, Figueiredo AG (2009) Performance maize genótipos with different amounts of oat straw and nitrogen. Brazilian Agricultural Research, Brasília. 44:173-179.

Ferreira DF (2011) Sisvar: a computer statistical analysis system. Science and Agrotecnologia (UFLA). 35:1039-1042.

Souza LPF (2016) Evaluation of nitrogen fertilization according to the population density of corn plants under no-tillage system in the State of Pará. UEPA, Belem. Dissertation (Master's).1:1-63.

Gomes RF, Silva AG, Assis RL, Pires FR (2007) Effect of doses and nitrogen application timing on agronomic traits of corn under no-tillage. Journal of Soil Science. 31: 931-938. 
Gross MR, Von Pinho RG, Brito AH (2006) Nitrogen seeding and spacing in maize in no-tillage system. Science and Agrotecnologia, Lavras.30:387-393.

Holland JE, Bennett AE, Newton AC, White PJ, McKenzie BM, George TS, Pakeman RJ, Bailey JS, Fornara DA, Hayes RC (2018) Liming impacts on soils, crops and biodiversity in the UK: a review. Sci Total Environ. 610-611:316-332.

Inmet - Instituto Nacional de Meteorologia (2015) rainfall and reative humidity in the year. Available in: http://www.inmet.gov.br/portal. Access on: april. 20st, 2015.

Kaneko FH, Arf O, Gitti DC, Arf MV, Chioderoli CA, Kappes C (2010) Soil management and nitrogen in maize grown in traditional small spacings. Bragantia, Campinas. 69: 677686.

Kappes C, Arf O, Edjair ADB, Portugal JR, Gonzaga AR (2014) Nitrogen management coverage in maize in no-till system. Journal of Maize and Sorghum. 13:201-217.

Kurihara H, Fabrizio AC, Pitol C, Staut LA, Kichel AN, Macedo MCM, Zimmer AH, Wietholter S (1998) Fertilization. In: SALTON, JC System till the producer asks, Embrapa answers. Brasília, DF: Embrapa-SPI, Golden: EmbrapaCPAO.1: 21-36

Melo FB, Korah JE, Cardoso MJ (2011) nitrogen fertilization, plant density and yield of corn grown in tillage. Agronomic Science magazine, Fortaleza. 42: 27-31.

Mendes MC, Rossi ES, Faria MV, Albuquerque CJB, Rosario JG (2011) Effects of levels of nitrogen fertilization and seed density in maize in South Central Paraná. Journal of Applied Technology in Agricultural Sciences, GuarapuavaPR. 4:176-192.

Merten GH, Araújo AG, Biscaia RCM, Barbosa GMC, Conteb O. (2015) No-till surface runoff and soil losses in southern Brazil. Soil Till Res. 152: 85-93.

Nogaroli JA, Fonseca AF (2020) Yield index of crops grown under no-tillage after superficial application of micronized liming materials (MLM) on the soil. AJCS. 14:187-195.

Okumura RS, Mariano DC, Zaccheo PVC (2011) Use of nitrogen fertilizer in maize: a review. Journal of Applied Technology in Agricultural Sciences, Guarapuava-PR. 4:226-244.
Oliveira SM, Almeida REM, Migliavacca RA, Favarin JL (2015) importance of the no-tillage system (SPD) for the corn crop. Agricultural View. 13: 40-44.

Queiroz AM, Souza CHE, Machado VJ, Lana RMQ, Korndörfer GH, Silva AA (2011) Evaluation of different sources and nitrogen fertilization doses of maize (Zea mays L.). Journal of Maize and Sorghum.10: 257-266.

Raij BV, Cantarella H, Quaggio JA, Furlani AMC (1996) Recommendations fertilization and liming for the State of São Paulo. Campinas IAC.Technical Bulletin. 100:1-285.

Raij BV (2011) Soil fertility and management of nutrients. Piracicaba IPNI1:1-420.

Sangoi L (2000) Understanding density effects on maize plant growth and development: an important issue to maximize grain yield. Rural Science. 31:159-168.

Santos LPD, Aquino LA, Nunes PHMP, Xavier FO (2013) Nitrogen doses in maize to high grain yield. Journal of Maize and Sorghum. 12:270-279.

Silva CE, Buzetti S, Guimaraes GL, Lazarini E, Sa ME (2005) Nitrogen doses and application times in corn under notillage on Rhodic. Journal of Soil Science. 29:353-362.

Valentinuzzi F, Mimmo T, Cesco S, Mamun SA, Santner J, Hoefer C, Oburger E, Robinson B, Lehto N (2015) The effect of lime on the rhizosphere processes and elemental uptake of white lupin. Environ Exp Bot. 118: 85-94.

Veloso, CAC, Franzini VI, Silva, ARB, Silva, AR (2012) Nitrogen fertilization in corn in the state of Para West. (Embrapa Eastern Amazon. Research and Development Bulletin. 1:184.

Von Pine RG, Gross MR, Steola AG, Mendes MC (2008) Nitrogen fertilization, density and spacing of maize hybrids in no-till system in southeastern Tocantins. Bragantia. 67: 733-739. 